BIOKEMISTRI 18(2):141-149 (December 2006)

Available online at http://www.bioline.org.br/bk and at http://www.ajol.info/journals/biokem

Printed in Nigeria

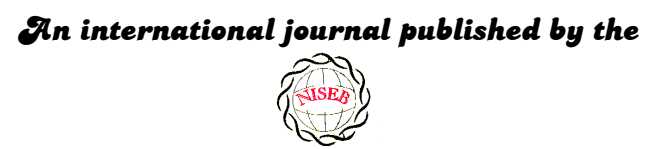

OVigerian Society for E̊xperimental ßiology

\title{
Chemical characteristics of palm oil biodeterioration
}

\author{
Uchechi N. EKWENYE
}

Department of Microbiology, Michael Okpara University of Agriculture, P.M.B 7267, Umuahia, Nigeria

\section{Received 2 August 2005}

MS/No BKM/2005/036, @ 2006 Nigerian Society for Experimental Biology. All rights reserved.

\begin{abstract}
Examination of the palm oil from dura and tenera varieties of the oil palm (Elaeis guineensis) Jacquin for growth of microorganisms (fungi and bacteria), revealed that tenera was more stable to bacteria and fungal deterioration while dura was less biostable. Determination of the chemical composition of the palm oil types revealed that crude protein contents of the fresh oil samples which ranged from 0.037 to $0.066 \%$ were lower than those kept under different conditions. A tenera oil sample (80S, sample 8) had the highest free fatty acid (14.76\%) while a dura oil sample (10 OJ, sample 10) had the lowest (4.46\%). The peroxide values (PV) of the fresh oil sample were low $(0.00-10.40 \mathrm{mEq} / \mathrm{kg})$. The iodine values of the fresh oil samples were lower $(23.57$ - 48.95) than those kept under different conditions $(40.32-70.43)$. Palm oils should not be stored for a long time because of deterioration.
\end{abstract}

Keywords: Palm oils, chemical characteristics, biodeterioration

*E-mail: ekwenyeuchechi@yahoo.com 


\section{INTRODUCTION}

Biodeterioration covers a wide range of biological activities where the effect is to "make things worse" and thus adversely affect man's economy ${ }^{1}$. Microorganisms are known to cause chemical characteristics that lead to deterioration in quality of vegetable oils derived from the seeds or fruits pulps of plants. The keeping quality of the oils is basically dependent on their chemical compositions, for instance, the percentages of the degree of unsaturation ${ }^{2}$.

Some slight deterioration at least is to expected in any commercial oil-bearing material and is, in fact, inherent in the process by which fat is formed. In the living plants and animals, fats, carbohydrates and proteins are synthesized in a complicated series of steps with the aid of certain enzymes. These enzymes are capable of assisting the reverse as well as the forward reactions and hence under proper conditions may promote the degradation of the very substances that, they have previously been instrumental in synthesizing ${ }^{3}$.

Oils in general are known to be susceptible to microbial attack. The composition of the various oils determines the extent and type of organisms likely to thrive in them ${ }^{4}$.

Palm oil is known to support the growth of fungi and bacteria especially when it contains moisture 5 . Their lipolytic enzymes are so active that even under unfavorable conditions palm oil is seldom produced with a free fatty acid content (FFA) of less than $2 \%$ and under favorable conditions of processing, the free fatty acid content of this oil reaches $20 \%$ and higher. When the fruit is bruised, lipolytic action occurs and a near maximum FFA $(8-10 \%)$ is reached within 40 minutes. The FFA of unbruised fruits may increase only $0.2 \%$ or less in the course of 4 days $^{3}$.

This study is aimed at examining the biodeteriogenic effects of microorganisms contaminating the oils from tenera and dura varieties of the oil palm (Elaeis guineensis) Jacquin and the chemical components of the oils.

\section{MATERIALS AND METHODS}

\section{Collection of samples}

The palm fruits used in this work were obtained from Elaeis guineensis dura (Ojukwu) and Elaeis guineensis tenera (Osukwu) varieties. Each sample of dura and tenera varieties was obtained from 5 locations in Abia State. Namely: Nvosi $(1,3)$, Ikputu $(2,4)$, Ndume $(5,6)$, Ubakala $(7,8)$ and Amawom $(9,10)$.

\section{Extraction of palm oil from mesocarp oil palm varieties}

A modification of the method of Anochili ${ }^{6}$ was used. The freshly harvested ripe oil palm fruits were separated from the bunch and boiled in a large container for about 4 hours. The mass of pulp was produced by pounding the boiled fruits in a special pit. The initial stages were carried out in the pit, the sides of which are coated with cement. The whole mass was immersed in water, stirred and the crude oil, which rose to the surface, was skimmed off into another pot. The fibres were then sifted out of the water manually and finally the nuts were collected and separated from the remaining fibres. The crude oil thus obtained was boiled in smaller vessels where any fibre still present sank to the bottom. The oil was again skimmed to further remove traces of water ${ }^{6}$.

\section{Isolation of fungi}

Sabouraud dextrose agar (temperature 45 $50^{\circ} \mathrm{C}$ ) in $9 \mathrm{ml}$ amounts was used as blank for diluting the oil samples kept under different conditions. Sterile streptomycin $(50 \mu \mathrm{g} / \mathrm{ml})$ was added to the Sabouraud dextrose agar to suppress bacterial growth. The agar medium was autoclaved at $121^{\circ} \mathrm{C}$ for 15 minutes and $1.05 \mathrm{~kg} / \mathrm{cm}^{2}\left(15 \mathrm{Ib} / \mathrm{in}^{2}\right)$. Oil samples were serially diluted in molten agar in test tubes, before pouring into sterile petri plates, one mililitre of $10^{-3}, 10^{-4}$ and $10^{-5}$ dilutions were used. The agar medium was allowed to cool and solidify before the plates were incubated 
at room temperature $\left(30 \pm 20^{\circ} \mathrm{C}\right)$ for $72-120$ hours. Fungal counts were taken from the oil sample kept under different conditions after incubation to represent the fungal load of the samples. A portion of each fungal colony which developed was picked using a sterile inoculating needle and aseptically subcultured on to fresh Sabouraud dextrose agar plates. The plates were kept as stock cultures for identification tests.

\section{Isolation of bacteria}

Molten nutrient agar (temperature $45-50^{\circ} \mathrm{C}$ ) in $9 \mathrm{ml}$ amounts was used as blank for diluting the oil samples kept under different conditions and $50 \mu \mathrm{g} / \mathrm{ml}$ nystatin was added to suppress fungal growth. The agar medium was autoclaved at $121^{\circ} \mathrm{C}$ for 15 minutes and $1.05 \mathrm{~kg} / \mathrm{cm}^{2}\left(15 \mathrm{Ib} / \mathrm{in}^{2}\right)$. The oil sample was treated as previously described for fungal growth. Viable aerobic bacterial counts were taken from the oil samples kept under different conditions after incubation to represent the bacterial load of the samples. Colonies were picked from the plates and streaked on fresh nutrient agar plates to purify. Pure cultures of the isolates were put on nutrient agar slants and stored in the refrigerator $\left(4^{0} \mathrm{C}\right)$ as stock cultures for identification tests.

\section{Determination of free fatty acid content}

The free fatty acid content of a fat/oil is the number of milligrammes of $\mathrm{KOH}$ required to neutralize $\lg$ of FFA present in fat/oil sample. The free fatty acid contents of the palm oil types/samples were determined according to the method described by Coursey $^{7}$. The acid value is the number of $\mathrm{mg}$ of $\mathrm{KOH}$ necessary to neutralize the free acid in $\lg$ of sample. The acid value is given by $\mathrm{T}-\mathrm{B} \times 5.61 / \mathrm{W}$

$0.1 \mathrm{M} \mathrm{KOH}$ contains $5.6 \mathrm{mg} / \mathrm{ml}$ or $5.6 \mathrm{~g} / \mathrm{l}$ where $\mathrm{T}=$ Titre value of the sample; $\mathrm{B}=$ Titre value of a blank. The blank was provided as a control by titrating $2.5 \mathrm{ml}$ of the neutral alcohol without sample. The free fatty acid (FFA) is normally determined as oleic acid where by the acid value $=2 \times$ FFA.

$\mathrm{NaOH}$ may be used and a generalized formula may be used (for palm oil and fractions): $25.6 \times \mathrm{MNaOH} \times \mathrm{V} / \mathrm{W}$ where $\mathrm{V}=$ Volume of $\mathrm{NaOH}$ solution used in $\mathrm{ml}$; $\mathrm{W}=$ Weight of sample

\section{Determination of iodine value}

Iodine number or value is a quantitative measure of the degree of unsaturation in a lipid. The principle of the assessment is based on the fact that halogens add to the double bonds of unsaturated fatty acids. The iodine value was determined by the PORIM Test Method ${ }^{8}$. Iodine value was calculated as $12.69 \mathrm{~N}\left(\mathrm{~V}_{2}-\mathrm{V}_{1}\right) / \mathrm{W}$ where $\mathrm{N}=$ Normality of $\begin{array}{llll}\mathrm{Na}_{2} & \mathrm{~S}_{2} & \mathrm{O}_{3} & \text { used; } \mathrm{W}=\text { the Volume in }\end{array}$ millilitres of $\mathrm{Na}_{2} \mathrm{~S}_{2} \mathrm{O}_{3}$ used (Blank); $\mathrm{V}_{1}=$ the Volume in millilitres of $\mathrm{Na}_{2} \mathrm{~S}_{2} \mathrm{O}_{3}$ solution used for the determination (test sample).

\section{Determination of peroxide value}

The peroxide value was determined by the method described by Pearson ${ }^{7}$ as the mg weight of iodine, which is formed by $1 \mathrm{~kg}$ of fat/oil sample. When potassium iodine was subjected to the oxidation effect of peroxide forming iodine at room temperature, the iodine, which was liberated, was titrated against standard sodium thiosulphate solution $\left(0.02 \mathrm{~N} \quad \mathrm{Na}_{2} \mathrm{~S}_{2} \mathrm{O}_{3}\right)$. The peroxide value was reported as the volume of $0.02 \mathrm{~N}$ $\mathrm{Na}_{2} \mathrm{~S}_{2} \mathrm{O}_{3}$ used in the titration ${ }^{7}$.

\section{Determination of crude protein}

The Kjeldahl procedure described by Pearson ${ }^{7}$ was used for the determination of nitrogen and crude protein contents of the oil samples. This method involved the determination of total nitrogen which was converted to protein.

\section{RESULTS AND DISCUSSION}

The viable counts of microbial organisms (fungi and bacteria) in the oil samples are shown in Tables 1 and 2. Low counts of fungal species were recorded in the fresh oil samples; oil kept in the laboratory (room temperature) for three months and refrigerated oils. Fairly high counts were recorded for oils kept in ambient temperature for 3 months and stale oils (stored under ambient temperature and room temperature). Although low counts of fungal 
Table 1: Fungal counts in the oil samples

\begin{tabular}{cccccc}
\hline $\begin{array}{c}\text { Oil } \\
\text { Samples }\end{array}$ & Fresh & $\begin{array}{c}\text { Kept at room } \\
\text { temperature for 3 } \\
\text { months }\left(\mathbf{3 0} \pm \mathbf{2}^{\mathbf{0}} \mathbf{C}\right)\end{array}$ & $\begin{array}{c}\text { Stored for one } \\
\text { year }\end{array}$ & $\begin{array}{c}\text { Kept in ambient } \\
\text { temperature for } \mathbf{3} \\
\text { months }(\mathbf{2 8} \mathbf{3 2} \mathbf{C})\end{array}$ & $\begin{array}{c}\text { Refrigerated } \\
\left(\mathbf{4}^{\mathbf{0}} \mathbf{C}\right)\end{array}$ \\
\hline 1 OS & $40 \pm 0.00$ & $50 \pm 0.24$ & $1.90 \pm 0.89 \times 10^{3}$ & $5.00 \pm 0.73 \times 10^{2}$ & $45 \pm 2.49$ \\
2 OS & $50 \pm 0.24$ & $50 \pm 0.00$ & $1.68 \pm 0.28 \times 10^{3}$ & $7.60 \pm 0.29 \times 10^{2}$ & $57 \pm 4.02$ \\
3 OJ & $60 \pm 0.24$ & $80 \pm 0.43$ & $2.08 \pm 0.71 \times 10^{3}$ & $1.80 \pm 0.14 \times 10^{2}$ & $63 \pm 5.16$ \\
4 OJ & $40 \pm 0.43$ & $80 \pm 0.50$ & $1.12 \pm 0.79 \times 10^{3}$ & $2.06 \pm 0.44 \times 10^{3}$ & $60 \pm 9.04$ \\
5 OS & $40 \pm 0.00$ & $50 \pm 0.00$ & $3.80 \pm 0.19 \times 10^{2}$ & $4.00 \pm 0.00 \times 10^{2}$ & $50 \pm 7.08$ \\
6 OJ & $40 \pm 0.24$ & $50 \pm 0.24$ & $4.40 \pm 0.35 \times 10^{2}$ & $1.88 \pm 0.29 \times 10^{3}$ & $40 \pm 4.30$ \\
7 OJ & $60 \pm 0.24$ & $80 \pm 0.43$ & $1.28 \pm 0.71 \times 10^{3}$ & $7.80 \pm 0.14 \times 10^{2}$ & $63 \pm 6.24$ \\
8 OS & $30 \pm 0.00$ & $50 \pm 0.24$ & $1.90 \pm 0.89 \times 10^{3}$ & $1.70 \pm 0.73 \times 10^{3}$ & $40 \pm 5.04$ \\
9 OS & $40 \pm 0.24$ & $60 \pm 0.00$ & $1.76 \pm 0.14 \times 10^{3}$ & $2.36 \pm 0.29 \times 10^{3}$ & $40 \pm 4.30$ \\
10 OS & $60 \pm 0.24$ & $80 \pm 0.24$ & $2.20 \pm 0.17 \times 10^{3}$ & $4.60 \pm 0.44 \times 10^{2}$ & $70 \pm 2.49$ \\
\hline
\end{tabular}

$O S=O s u k w u ; O J=O j u k w u$

The counts are means of three replicates \pm standard deviation.

Table 2: Total viable counts of aerobic heterotrophic bacteria in the oil samples

\begin{tabular}{|c|c|c|c|c|c|}
\hline $\begin{array}{c}\text { Oil } \\
\text { Samples }\end{array}$ & Fresh & $\begin{array}{c}\text { Kept at room } \\
\text { temperature for } 3 \\
\text { months }\left(30 \pm 2^{0} \mathrm{C}\right)\end{array}$ & $\begin{array}{c}\text { Stored for one } \\
\text { year }\end{array}$ & $\begin{array}{l}\text { Kept in ambient } \\
\text { temperature for } 3 \\
\text { months }\left(28-32^{0} \mathrm{C}\right)\end{array}$ & Refrigerated $\left(4^{0} \mathrm{C}\right)$ \\
\hline $1 \mathrm{OS}$ & $2.70 \pm 0.57 \times 10^{3}$ & $2.00 \pm 0.60 \times 10^{2}$ & $3.70 \pm 0.24 \times 10^{3}$ & $2.1 . \pm 0.86 \times 10^{3}$ & $3.30 \pm 0.89 \times 10^{3}$ \\
\hline $2 \mathrm{OS}$ & $3.33 \pm 0.33 \times 10^{3}$ & $1.94 \pm 0.97 \times 10^{2}$ & $3.70 \pm 0.00 \times 10^{3}$ & $1.94 \pm 0.53 \times 10^{3}$ & $3.70 \pm 0.24 \times 10^{3}$ \\
\hline $3 \mathrm{OJ}$ & $2.60 \pm 0.42 \times 10^{3}$ & $3.10 \pm 0.29 \times 10^{2}$ & $8.00 \pm 0.24 \times 10^{3}$ & $1.63 \pm 0.42 \times 10^{3}$ & $3.70 \pm 0.24 \times 10^{3}$ \\
\hline $4 \mathrm{OJ}$ & $3.00 \pm 0.11 \times 10^{3}$ & $1.60 \pm 0.14 \times 10^{2}$ & $7.80 \pm 0.24 \times 10^{3}$ & $1.56 \pm 0.43 \times 10^{3}$ & $3.50 \pm 0.71 \times 10^{3}$ \\
\hline $5 \mathrm{OS}$ & $3.01 \pm 0.05 \times 10^{3}$ & $1.90 \pm 0.49 \times 10^{2}$ & $5.80 \pm 0.24 \times 10^{2}$ & $1.29 \pm 0.30 \times 10^{3}$ & $3.70 \pm 0.65 \times 10^{3}$ \\
\hline $6 \mathrm{OJ}$ & $3.67 \pm 0.35 \times 10^{3}$ & $1.60 \pm 0.14 \times 10^{2}$ & $5.90 \pm 0.24 \times 10^{2}$ & $1.61 \pm 0.42 \times 10^{3}$ & $3.80 \pm 0.24 \times 10^{3}$ \\
\hline $7 \mathrm{OJ}$ & $3.67 \pm 0.03 \times 10^{3}$ & $8.00 \pm 0.81 \times 10^{1}$ & $8.20 \pm 0.24 \times 10^{3}$ & $1.11 \pm 0.27 \times 10^{3}$ & $3.60 \pm 0.00 \times 10^{3}$ \\
\hline $8 \mathrm{OS}$ & $3.12 \pm 0.11 \times 10^{3}$ & $2.30 \pm 0.13 \times 10^{2}$ & $5.60 \pm 0.49 \times 10^{3}$ & $7.80 \pm 0.21 \times 10^{2}$ & $3.70 \pm 0.00 \times 10^{3}$ \\
\hline $9 \mathrm{OS}$ & $3.67 \pm 0.24 \times 10^{3}$ & $3.20 \pm 0.27 \times 10^{2}$ & $6.80 \pm 0.00 \times 10^{3}$ & $3.86 \pm 0.10 \times 10^{2}$ & $3.90 \pm 0.00 \times 10^{3}$ \\
\hline $10 \mathrm{OS}$ & $3.73 \pm 0.37 \times 10^{3}$ & $1.00 \pm 0.12 \times 10^{2}$ & $7.80 \pm 0.24 \times 10^{3}$ & $4.53 \pm 0.99 \times 10^{2}$ & $3.90 \pm 0.24 \times 10^{3}$ \\
\hline
\end{tabular}

$O S=O s u k w u ; O J=O j u k w u$

The counts are means of three replicates \pm standard deviation. 
species were recorded (Table 1), spores were present in the oils. The proliferation of these fungi can therefore occur if there is accidental wetting or careless handling as the oils absorb moisture from the atmosphere. Most of the fungi isolated from the oil samples are known to be actively lipolytic $(9 ; 10)$ and so are capable of eventually lipolysing the oils especially if storage is prolonged. In fresh oil samples, the fungal count of tenera is lower than that of dura. This suggests that tenera oil is more stable to fungal deterioration while dura oil is less biostable. A similar fungal count was exhibited for oils kept in the laboratory for 3 months and refrigerated oils. A similar fungal count was also exhibited for stale oils except oil sample 60J (dura oil sample 6). A similar fungal count was also exhibited for oils kept in ambient temperature for 3 months except $30 \mathrm{~J}$ (dura oil sample 3 ).

High counts of aerobic heterotrophic bacteria species were recorded in all the oil samples under different conditions except the oils kept in the laboratory (room temperature) for 3 months. In the stale oils, higher bacterial counts were recorded in dura oil samples than in the tenera samples. This suggests that tenera oil is more stable to bacterial deterioration while dura oil is less biostable. However, the highest bacterial counts were recorded for the stale oils. The results indicate the levels of deterioration of the oils during processing and handling as well as the survival of bacterial cells in the oils under room temperature, ambient temperature and refrigeration.

Table 3: Chemical compositions of the oil types

\begin{tabular}{lcccc}
\hline \multicolumn{2}{l}{ a. Fresh oils } & & & \\
\hline Samples & $\begin{array}{c}\text { Proteins } \\
\text { \% }\end{array}$ & $\begin{array}{c}\text { FFA } \\
\mathbf{\%}\end{array}$ & $\begin{array}{c}\text { PV } \\
(\mathbf{m E q} / \mathbf{k g})\end{array}$ & IV \\
\hline 1 OS & 0.056 & 9.98 & 2.80 & 45.95 \\
2 OS & 0.053 & 8.33 & 4.80 & 48.96 \\
3 OJ & 0.040 & 7.33 & 5.20 & 43.51 \\
4 OJ & 0.049 & 8.60 & 4.60 & 40.25 \\
5 OS & 0.037 & 6.02 & 0.00 & 45.32 \\
6 OJ & 0.053 & 6.11 & 1.40 & 33.37 \\
7 OS & 0.047 & 4.23 & 10.40 & 23.57 \\
8 OS & 0.054 & 14.76 & 6.40 & 48.95 \\
9 OS & 0.066 & 10.81 & 0.00 & 40.61 \\
10 OJ & 0.066 & 4.46 & 0.00 & 44.81 \\
\hline
\end{tabular}

The crude protein free fatty acid (FFA), peroxide value and iodine values (IV) of the oil samples are presented in Table 3. The crude protein content of the fresh oil samples was lower than the level in oil samples kept under room temperature, variable conditions, ambient temperature and refrigeration. The protein content increased in the oils kept in the laboratory for 3 months.

\begin{tabular}{lcccc}
\hline $\begin{array}{l}\text { b. Oils } \\
\text { temperature) for }\end{array}$ & $\begin{array}{c}\text { k } \\
\text { months }\end{array}$ & laboratory & (room \\
\hline Samples & $\begin{array}{c}\text { Proteins } \\
\text { \% }\end{array}$ & $\begin{array}{c}\text { FFA } \\
\text { \% }\end{array}$ & $\begin{array}{c}\text { PV } \\
(\mathbf{m E q} / \mathbf{k g})\end{array}$ & IV \\
\hline 1 OS & 0.219 & 13.06 & 1.90 & 57.10 \\
2 OS & 0.219 & 10.45 & 2.40 & 70.43 \\
3 OJ & 0.219 & 9.57 & 3.40 & 59.77 \\
4 OJ & 0.263 & 15.67 & 2.20 & 53.30 \\
5 OS & 0.238 & 8.19 & 0.80 & 67.38 \\
6 OJ & 0.131 & 11.84 & 3.20 & 68.15 \\
7 OJ & 0.219 & 7.34 & 1.80 & 60.91 \\
8 OS & 0.131 & 21.93 & 1.00 & 64.72 \\
9 OS & 0.176 & 7.93 & 0.60 & 66.62 \\
10 OJ & 0.131 & 5.51 & 6.80 & 61.29 \\
\hline
\end{tabular}

\begin{tabular}{|c|c|c|c|c|}
\hline \multicolumn{5}{|c|}{$\begin{array}{l}\text { c. Stale oils (stored under variables } \\
\text { conditions for } 1 \text { year) }\end{array}$} \\
\hline Samples & $\begin{array}{l}\text { Proteins } \\
\quad \%\end{array}$ & $\begin{array}{c}\text { FFA } \\
\%\end{array}$ & $\underset{(\mathbf{m E q} / \mathbf{k g})}{\mathbf{P V}}$ & IV \\
\hline $1 \mathrm{OS}$ & 0.219 & 7.90 & 0.20 & 62.66 \\
\hline $2 \mathrm{OS}$ & 0.219 & 17.60 & 6.60 & 43.44 \\
\hline $3 \mathrm{OJ}$ & 0.219 & 7.06 & 20.00 & 59.59 \\
\hline $4 \mathrm{OJ}$ & 0.219 & 8.70 & 9.60 & 57.67 \\
\hline $5 \mathrm{OS}$ & 0.219 & 7.90 & 2.80 & 56.13 \\
\hline $6 \mathrm{OJ}$ & 0.431 & . & 0. & 57.07 \\
\hline $7 \mathrm{OJ}$ & 0.219 & 7.90 & 2.80 & 56.13 \\
\hline $8 \mathrm{OS}$ & 0.219 & 16.60 & 8.2 & 58.80 \\
\hline $9 \mathrm{OS}$ & 0.219 & 15.00 & 1.40 & 56.50 \\
\hline $10 \mathrm{OJ}$ & 0.431 & 5.82 & 3.70 & 57.00 \\
\hline
\end{tabular}

\begin{tabular}{ccccc}
\hline \multicolumn{5}{c}{ d. Oils kept in ambient temperature 3 months } \\
\hline Samples & $\begin{array}{c}\text { Proteins } \\
\text { \% }\end{array}$ & $\begin{array}{c}\text { FFA } \\
\text { \% }\end{array}$ & $\begin{array}{c}\text { PV } \\
(\mathbf{m E q} / \mathbf{k g})\end{array}$ & $\mathbf{I V}$ \\
\hline 1 OS & 0.200 & 12.19 & 0.33 & 49.58 \\
2 OS & 0.175 & 10.45 & 8.33 & 67.24 \\
3 OJ & 0.175 & 9.93 & 5.00 & 54.47 \\
4 OJ & 0.175 & 8.19 & 0.57 & 47.33 \\
5 OS & 0.156 & 8.19 & 0.00 & 32.68 \\
6 OJ & 0.219 & 11.49 & 0.63 & 37.19 \\
7 OJ & 0.175 & 8.01 & 5.46 & 46.200 \\
8 OS & 0.219 & 24.02 & 0.57 & 50.10 \\
9 OS & 0.219 & 18.46 & 0.33 & 51.52 \\
10 OJ & 0.175 & 4.53 & 6.30 & 30.80 \\
\hline
\end{tabular}




\begin{tabular}{ccccc}
\hline \multicolumn{6}{l}{ e. Refrigerator Oils } \\
\hline Samples & $\begin{array}{c}\text { Proteins } \\
\mathbf{\%}\end{array}$ & $\begin{array}{c}\text { FFA } \\
\mathbf{\%}\end{array}$ & $\begin{array}{c}\text { PV } \\
(\mathbf{m E q} / \mathbf{k g})\end{array}$ & IV \\
\hline 1 OS & 0.096 & 12.60 & 8.90 & 56.97 \\
2 OS & 0.101 & 8.60 & 6.20 & 56.53 \\
3 OJ & 0.176 & 8.00 & 22.00 & 45.14 \\
4 OJ & 0.146 & 8.80 & 14.00 & 62.67 \\
5 OS & 0.218 & 7.90 & 4.10 & 40.32 \\
6 OJ & 0.113 & 8.90 & 3.00 & 60.04 \\
7 OJ & 0.131 & 6.00 & 11.43 & 63.02 \\
8 OS & 0.219 & 19.20 & 7.33 & 62.67 \\
9 OS & 0.175 & 15.00 & 4.10 & 56.97 \\
10 OJ & 0.219 & 4.90 & 4.10 & 59.16 \\
\hline \multicolumn{5}{l}{ OS = Osukwu; OJ=Ojukwu } \\
\end{tabular}

In the stale oil samples, only 60J (dura oil samples 6) and 100J (dura oil sample 10) had the highest protein contents. For oils kepts in ambient temperature for 3 months there was a decrease in the protein contents of the oil samples except 80S (tenera oil sample 8) and 90S (tenera oil sample 9). For the refrigerated oils only $80 \mathrm{~S}$ (tenera oil sample 8) and 100S (tenera oil sample 10) had the highest protein contents. The crude protein contents in fresh oil samples were low but increased under room temperature, ambient temperature and refrigeration. Moreover, Akpanabiatu et $a l^{11}$ reported that the tenera variety is richer in fat, ash and organic matter than the dura while the dura is richer in crude protein and fiber.

Deterioration of a fat leads to the liberation of free fatty acids (FFA) from triglycerides. The amount of free fatty acid (FFA) in a fat or oil is indicative of its level of spoilage. In the fresh oil samples, 80S (tenera oil sample 8 ) showed the highest amount of FFA. The highest level of FFA was recorded for $80 \mathrm{~S}$ (tenera oil sample 8) for the samples kept in the laboratory. For the stale oils, the highest amount of FFA was recorded for $10 \mathrm{~S}$ (tenera oil sample 1) followed by $80 \mathrm{~S}$ (tenera oil sample 8). The result indicated that $80 \mathrm{~S}$ (tenera oil sample 8) had the highest level of spoilage and 100J (dura oil sample 10) had the lowest level of spoilage. These results are similar to those of Egan et $a l^{12}$ who reported that FFA/acid value is a measure of the extent to which the glycerides in the oil have been decomped by lipase or other action and that decomposition is accelerated by heat and light. The results of FFA determination in Table 3 is in agreement with those of Ekpa and Ekpe ${ }^{13}$ who reported that oil samples exposed to normal room conditions (room temperature, $28^{\circ} \mathrm{C}$ ) were observed to have higher FFA values than the corresponding unexposed samples. However, Ekpa et $\mathrm{al}^{14}$ reported that dura variety, in general, exhibited higher values of FFA than the tenera variety. Another report by Ekpa et $a l^{15}$ showed that there were significant $(\mathrm{P}<0.05)$ variations in the major constituent fatty acids among the varieties.

Palm oil from red tenera had a mean palmitic acid content of $460.7 \mathrm{gkg}^{-1}$ compared with $404.1 \mathrm{gkg}-1$ for red dura oil (RDPO) while their oleic acid contents were 348.5 and $416.4 \mathrm{gkg}-1$ respectively. They also reported that there were significant differences observed between palm oils from the red and yellow fruits of the same variety. Other reports ${ }^{15,16}$ also showed that the mean total fatty acids calculated for the oil samples showed that the dura is richer in unsaturated fatty acids in all locations than the tenera varieties. The high level of unsaturation in the dura makes it preferable and more adequate nutritionally than the tenera. Since the level of unsaturation is affected by the environment where the oil palm is grown, a careful selection of planting location is necessary, if high unsaturation to saturation ratio is desired. In addition, Ekpa and Ekpe $^{13}$ reported significant differences $(\mathrm{P}<0.05)$ in free fatty acid contents for palm oils from the red and yellow dura and tenera fruits. The FFA was higher in the DRPO $(2.90 \%)$ than the corresponding TRPO (2.20\%) while essentially equal amounts were recorded for the yellow fruits of the two varieties (TYRO, 1.38\% and DYPO, 1.30\%) ${ }^{15}$.

The peroxide value (PV) of the fresh oil samples showed no values for 50S (tenera oil sample 5), 90S (tenera oil sample 9) and 100S (dura oil sample 10). This might be as a result of the freshness of the oil values 
except $70 \mathrm{~J}$ (dura oil sample 7). The peroxide value of the oils kept in the laboratory for 3 months were low. For the stale oils, the highest peroxide value was observed for 3 OJ (dura oil samples 3). The PV of oils kept in ambient temperature for 3 months were low and 50S (tenera oil sample 5) had no value. Higher peroxide values were observed for the refrigerated oils and the highest was recorded for 3 OJ (dura oil sample 3). The spoilage of fats and oils during storage is called rancidity and is associated with the production of foul odours ${ }^{17}$. The result recorded for the PV of oil samples is similar to those of Egan et $a l^{12}$ who reported fresh oils usually have peroxide values well below $10 \mathrm{mEq} / \mathrm{kg}$. A rancid taste often begins to be noticeable when the peroxide value is between 20 and $40 \mathrm{mEq} / \mathrm{kg}$. Ekpa and $\mathrm{Ekpe}^{13}$ reported that palm oil samples obtained from red and yellow fruits of the dura variety (DRPO and DYPO) had higher peroxide values (1.51 and 1.32 respectively) than the values for palm oils from the corresponding tenera variety ( 0.70 for TRPO and 0.80 for TYPO).

Metallic impurities particularly, iron and copper are pro-oxidants and are undesirable. They accelerate the rate of peroxide formation in the oil ${ }^{18}$, while the presence of natural antioxidants for example tocopherols, or synthetic anti-oxidants inhibit the formation of peroxides ${ }^{12}$. Peroxide value determines the degree of oxidation of the oil. The peroxide value alone is unreliable because it cannot measure products of secondary oxidation. Anisidine value and carbonyl value are commonly in use ${ }^{18}$. Palm oil oxidation has been the subject of much research. The two main parameters, peroxide value $(\mathrm{PV})$ and $\mathrm{P}$-anisidine value (AV) are regularly used as criteria of the oxidation state of the oil. Total oxidation (TOTOX) is taken as $2 x P V+A V$ ${ }^{19}$. Very little information is available on the degree of oxidation of traditionally produced palm oils ${ }^{19}$. A comparison ${ }^{20}$ of traditional palm oils produced in West Africa based on the work of $\mathrm{Ata}^{21}$, showed these oils had low peroxide values comparable in range to those found in Malaysian crude palm oil. By itself, however peroxide is not very useful as a guide because it is readily destroyed by heat. Peroxide must be measured in conjunction with P-anisidine value, the latter increases when peroxides decompose ${ }^{19}$. The report ${ }^{19}$ is in accordance with the PV results recorded for oils kept in ambient temperature for 3 months, unlike the refrigerated oils.

Oil samples 50S (tenera oil sample 5) and 90S (tenera oil sample 9) were observed to solidify at room temperature. This is in accordance with Egan et $a l^{12}$ who reported that for natural oils and fats the less unsaturated fats with low iodine values are solid at room temperature or conversely, oils that are more highly unsaturated are liquids (showing there is a relationship between melting points and iodine values (IV)). This suggests that 50S (tenera oil sample 5) and 90S (tenera oil sample 9) with iodine values of 67.38 and 66.62 respectively, were less unsaturated and the other oil samples highly unsaturated. In general, the greater the degree of unsaturation (high IV), the more readily the oil or fat becomes rancid. The lowest iodine value (IV) was recorded for 70J (dura oil sample 7) for fresh samples. For oils kept in the laboratory for 3 months, the highest IV was recorded for 20S (tenera oil sample 2). The IV recorded for the stale oils were high. The lowest IV was recorded for oil samples kept in ambient temperature for 3 months.

The IV recorded for the refrigerated oils were high. The iodine value is a useful index to detect adulteration of palm oil with any other vegetable or animal fat. Most vegetable oils are predominantly unsaturated and have high iodine value whereas animal fats tend to be predominantly saturated and show low iodine values ${ }^{18}$. The differences in the FFA and melting point (MP) profiles of dura and tenera oils were explained in terms of differences in the level of chain packing of the constituent fatty acids of the individual oils ${ }^{14,16}$. In accordance with the report of Egan et $a l^{12}$, the oils kept in the 
laboratory for 3 months and stale oils were more liable to become rancid.

In conclusion, the viable counts of microbial numbers (fungi and bacteria) contaminating the oils from tenera and dura varieties of the oil palm (Elaeis guineensis) Jacquin kept under different conditions were determined. The chemical components of the oils kept under different conditions were also determined. The oil merchants are therefore advised not to store palm oils for a long time, be it under ambient temperature or variable conditions.

\section{REFERENCES}

1.Barry, S. and Houghton, D. R. (1984) Deterioration of materials by Microorganisms. Proceedings of the $6^{\text {th }}$ International Biodeterioration Symposium C.A.B International Farnham House, Farnham Royal Slough, United Kingdom.

2.Okpokwasili, G. C. and Molokwu, C. N. (1996) Biochemical Characteristics of Vegetable oil Biodeterioration. Material und Organismen 30:307-314.

3.Norris, F. A. (1979) Handling Storage and Grading of Oils and Oil-Bearing Materials. In: Bailey's Industrial Oil and Fat Products. John Wiley and Sons, Inc. New York, Pp $479-510$.

4.Okpokwasili, G. C. and Williams, T. O. (1991) Stability to Deterioration of Vegetable Oil Biodeterioration. Material und Organismen 26:53-62.

5.Coursey, D. G. (1963) The Deterioration of Palm Oil during Storage. J West African Sci. Assoc. 7:101-13.

6.Anochili, B. C. (1986) Tropical Agricultural Handbook: Cash Crops. Macmillian Publishers, Ibadan, Pp. 5467.

7.Pearson, D. (1976) The Chemical Analysis of Foods. $7^{\text {th }}$ Edition, Edinburgh (Churchill Livingstone).

8.Palm Oil Research Institute of Malaysia (PORIM) (1990) The PORIM Test Method. Palm Oil Research Institute of Malaysia.
9.Kuku, F. O. (1976) Some Mould-induced Changes in Palm Kernels. Nig Stored Products Res Inst Tech Rep 9:62-72.

10.Frazier, W. C. and Westhoff, D. C. (1991) Food Microbiology Tata McGraw - Hill Publishing Co. Ltd, New Delhi, Pp 540.

11.Akpanabiatu, M. I. Ekpa, O. D. , Mauro, A. and Rizzo, R. (2001) Nutrient Composition of Nigerian Palm Kernel from Dura and Tenera Varieties of the Oil Palm (Elaeis guineensis). Food Chem. 72:173-177.

12.Egan, H. , Kirk, R. S. and Sawyer, R. (1981) Pearson's Chemical Analysis of Food. $8^{\text {th }}$ ed. Churchill Livingstone, New York, Pp 507-546.

13.Ekpa, O. D. and Ekpe, U. J. (1996) Effect of Coconut Oil Concentration on the Melting point profile and Free Fatty Acid Formation of Palm Oil. Nig. J. Chem. Res. 1 8-12.

14.Ekpa, O. D., Akpanabiatu, M. I., Amelio, M. and Rizzo, R. (2001) A Varietal Differences and Polymorphism in Palm Oil: A Case Study of Palm Oil Blended with coconut Oil. Global J. Pure \& Applied Sci. 7:277-283.

15.Ekpa, O. D., Fabara, E. P. and Morah, F. N. I. (1994) Variation in Fatty Acid Composition of Palm Oils from two Varieties of the Oil Palm (Elaeis guineensis) J. Sci. Food Agric. 64 483486.

16.Ekpa, O. D., Akpanabiatu, M. I., Amelio, M. and Rizzo, R (2001b) A Comparative Study of the Triglyceride and Fatty Acid Compositions of Palm Oil from Plantations in South-Eastern Nigeria. Global J. Pure \& Applied Sci. 7:61-65.

17.Ojiako, O. A. and Akubugwo, E. I. (1997) An Introductory Approach to Practical Biochemistry CRC Publications, Owerri, Pp. 132.

18.Okiy, D. A. (1979) Aspects on Quality of Palm Oil. NIFOR Newsletter No. 18 Pp 7-8.

19.Cornelius, J. A. (1984) Comparison of Traditional and Industrial Palm Oil. Oil Palm News No. 28. Tropical 
Development and Research Institute, London.

20.Rutowski, A. (1983) Traditional Palm Oil Processing in Western Africa. Fette Seifen Anstrichmittel 85:262 - 267.
21. Ata, J. K. B. A. (1974) Processing and Quality Characteristics of Ghanaian Commercial Palm Oils. Ghana Agric. Sci. 7:147-149. 